\title{
MENINGKATKAN KEMAMPUAN MENYIMPULKAN ISI TEKS LAPORAN HASIL OBSERVASI MENGGUNAKAN MODEL PROBLEM CENTERED LEARNING SISWA KELAS VII SMPN 2 GUNUNGSITOLI UTARA
}

\begin{abstract}
Abstrak
Permasalahan yang dikaji dalam penelitian ini, yaitu kemampuan siswa yang masih kurang dalam menyimpulkan isi teks laporan hasil observasi. Hal ini dipengaruhi oleh model pembelajaran yang digunakan guru dalam mengajar masih monoton. Model Problem Centered Learning merupakan pembelajaran yang sangat potensial digunakan supaya permasalahan yang diberikan diselasaikan dalam kolaboratif group. Penelitian ini bertujuan untuk (1) mengetahui peningkatan kemampuan siswa menyimpulkan laporan hasil observasi; dan (2) mengetahui aktivitas siswa dalam mengikuti proses. Penelitian ini merupakan Penelitian Tindakan Kelas (PTK) yang dilaksanakan selama dua siklus. Hasil penelitian yaitu penilaian sikap spritual dan sosial pada siklus I masih predikat cukup, tetapi pada siklus II mencapai predikat baik. Hasil analisis data tes pengetahuan pada siklus I rata-rata nilai $=59,25$ (predikat "kurang"), Nilai pengetahuan pada siklus II rata-rata $=85,35$ (predikat "Sangat Baik"). Hasil analisis data observasi aktivitas siswa pada siklus I pertemuan pertama $=$ rata-rata $47,21 \%$ dan pertemuan kedua $57,53 \%$ dan peretemuan ketiga $=63,48 \%$ (predikat "kurang"), dan siklus II pertemuan pertama $=$ rata-rata $65,86 \%$ dan pertemuan kedua rata-rata $73,80 \%$ (predikat "cukup") dan pertemuan ketiga $=80,15 \%$ predikat baik. Hasil observasi peneliti pada siklus I pertemuan pertama rata-rata $58,82 \%$ dan pertemuan kedua rata-rata 70,58\% dan pertemuan ketiga $=76,47 \%$ predikat kurang, dan pada siklus II pertemuan pertama meningkat rata-rata $82,35 \%$ dan pada pertemuan kedua rata-rata $88,23 \%$ dan pertemuan ketiga $=94,11 \%$.
\end{abstract}

Kata Kunci: Menyimpulkan isi Teks Laporan Hasil Observasi, Model Pembelajaran Problem Centered Learning

\begin{abstract}
The problems studied in this study were the students' lack of ability to conclude the ontents of the observation report text. This is influenced by the learning model used by the teacher in teaching which is still monotonous. The Problem-Centered Learning model is a learning that has the potential to be used so that the problems given are resolved in a collaborative group. This study aims to (1) determine the increase in students' ability to conclude the observation result report; and (2) knowing student activities in following the process. This research is a Classroom Action Research (CAR) which was conducted for two cycles. The result of this research is that the assessment of spiritual and social attitudes in the first cycle is still in the sufficient predicate, but in the second cycle it is in the good predicate. The results of the analysis of the knowledge test data in the first cycle had an average value of $=59.25$ (predicate "less"), the average value of knowledge in the second cycle $=85.35$ (predicate "Very Good"). The results of the analysis of student activity observation data in the first cycle of the first meeting $=$ an average of $47.21 \%$ and the second meeting of $57.53 \%$ and the third meeting $=63.48 \%$ (predicate "less"), and the
\end{abstract}

\footnotetext{
${ }^{1}$ Pendidikan Bahasa dan Sastra Indonesia, FPBS, IKIP Gunungsitoli e-mail : noveriharefa@gmail.com
} 
second cycle of the first meeting $=$ average $65.86 \%$ and the second meeting with an average of $73.80 \%$ (predicate "sufficient") and the third meeting $=80.15 \%$ good predicate. The results of observations of researchers in the first cycle of the first meeting an average of $58.82 \%$ and the second meeting an average of $70.58 \%$ and the third meeting $=76.47 \%$ predicate less, and in the second cycle the first meeting increased an average of $82.35 \%$ and at the second meeting an average of $88.23 \%$ and the third meeting $=94.11 \%$.

Keywords: Summing up the contents of the Text of the Observation Result Report, Problem Centered Learning Learning Model

\section{PENDAHULUAN}

Salah satu kegiatan membaca yang tercantum di dalam Kurikulum 2013 pada silabus tingkat SMP, yaitu terdapat pada KD 4.7: menyimpulkan isi teks laporan hasil observasi yang berupa buku pengetahuan yang dibaca dan didengar dengan indikator: (1) menentukan gagasan pokok teks laporan hasil observasi; (2) menentukan informasi rinci teks laporan hasil observasi; (3) menjawab pertanyaan tentang isi teks laporan hasil observasi.

Hasil observasi dan wawancara peneliti kepada guru dan siswa di SMPN 2 Gunungsitoli Utara di kelas VII, kemampuan siswa dalam menyimpulkan isi teks laporan hasil observasi masih sangat rendah. Hal itu terjadi dikarenakan siswa masih belum sepenuhnya memahami teks laporan hasil observasi, siswa belum mengerti tujuan komunikasi teks laporan hasil observasi, siswa belum menguasai prinsip pengembangan isi pada teks laporan hasil observasi, jenis kata/ kalimat/kata sambung yang digunakan pada laporan hasil observasi masih belum dipahami, siswa belum mampu menentukan gagasan pokok, dan siswa masih belum bisa menyimpulkan isi teks laporan hasil observasi yang dibaca. Selain hal tersebut, peneliti menemukan permasalah lain di dalam proses pembelajran diantaranya: 1) proses belajar mengajar guru masih belum sesuai dengan RPP yang disusun; 2) model serta metode pembelajaran yang digunakan belum inovatif; 3) media pembelajaran yang digunakan masih belum bisa memotivasi siswa dalam belajar; 4) serta kurangnya perhatian guru kepada siswa ketika mengajar di kelas. Berdasarkan permasalahn tersebut, peneliti mencari solusi dengan menerapkan salah satu model pembelajaran.

Teks laporan hasil observasi adalah laporan yang dilakukan oleh siswa terhadap pengamatan suatu objek yang dapat dilihat oleh mereka sehingga dapat didata dan kevalidan datanya bisa dibuktikan secara nyata di muka umum serta ruang lingkup yang diteliti atau diamati pun harus benar-benar pasti tidak boleh berubah-ubah untuk menentukan ke-berhasilan dari observasi tersebut. Kosasih (2013:49) mengatakan teks laporan observasi memiliki struktur teks yaitu mencakup pendahuluan, pembahasan, dan simpulan. Teks itu dapat pula dilengkapi dengan kata pengantar, daftar isi, dan daftar pustaka.

Instarani (2012:37), mengungkapkan bahwa Problem-Centered Learning (PCL) yaitu rangkaian aktivitas pembelajaran yang menekankan kepada proses penyelesaian masalah yang dihadapi secara ilmiah Instarani. Langkah-langlah model Pembelajaran Problem Centered Learning (PCL) adalah sebagai berikut.

1) Menyadari Masalah.

Siswa harus menyadari bahwa dalam belajar terdapat masalah atau kesenjangan yang dirasakan oleh manusia sosial yang harus diselesaikan.

2) Merumuskan Masalah.

Bahan pelajaran dalam bentuk topik yang dapat dicari dari kesenjangan, selanjutnya difokuskan pada masalah apa yang pantas untuk dikaji. Perlu ada kejelasan, data-data apa yang harus dikumpulkan untuk menyelesaikannya.

3) Merumuskan Hipotesis.

Siswa menentukan berbagai kemungkinan penyelesaian masalah.

4) Mengumpulkan Data

Siswa mengumpulkan data yang relevan, memetakan, dan menyajikannya. 
5) Menguji Hipotesis

Siswa menelaah data sekaligus membahasnya untuk melihat hubungannya dengan masalah yang dikaji dan mengambil keputusan.

6) Menentukan Pilihan Penyelesaian

Siswa cakap memilih alternatif penyelesaian yang memungkinkan yang akan dilakukan serta memperhintungkan kemungkinan yang akan terjadi sehubungan dengan alternatif yang dipiihnya.

1) Kelebihan Model Pembelajaran Problem Centered Learning (PCL)

Kelebihan penerapan model Pembelajaran Problem Centered Learning (PCL), adalah sebagai berikut:

a). PCL memfokuskan aktivitas pembelajaran pada berbagai masalah yang menarik bagi siswa, sehingga siswa selalu berusaha memecahkan masalah tersebut.

b). PCL memfokuskan pada pentingnya komunikasi dalam pembelajaran karena terdapat proses dimana siswa bekerja dalam kelompok secara kooperatif dan kolaboratif.

c). PCL ini memfokuskan pada proses-proses penyelidikan dan penalaran dalam pemecahan masalah dan bukan memfokuskan pada mendapatkan hasil-hasil eksperimen yang benar atau jawaban yang benar terhadap pertanyaan masalah semata.

d). PCL mengembangkan kepercayaan diri siswa dalam menggunakan atau menerapkan pembelajaran ketika mereka menghadapi situasi-situasi kehidupan sehari-hari (Sanjaya dalam Instarani 2012:52).

2) Kelemahan Model Pembelajaran Problem-Centered Learning (PCL)

a) Menentukan suatu masalah yang tingkat kesulitannya tinggi memerlukan kemampuan siswa dan keterampilan guru supaya tidak keliru.

b) Proses belajar memerlukan waktu yang cukup banyak dan sering terpaksa menggunakan waktu pelajaran lain.

\section{METODE}

Penelitian ini merupakan penelitian tindakan kelas (Classroom actionresearch) dengan menggunakan pendekatan mixing yaitu gabungan antara pendekatan kualitatif dan kuantitatif. Penelitian tindakan kelas adalah suatu proses di mana guru berkolaborasi dengan sejawat dalam mengevaluasi pelaksanaan pembelajaran, mencobakan strategi baru, dan mencatat apa yang mereka kerjakan selama penelitian dalam suatu format yang dapat dipahami guru-guru lain. Karakteristik utama dalam penelitian tindakan kelas adalah bersifat siklus, artinya penelitian tindakan kelas terikat oleh siklus-siklus. Arikunto (2007:3) berpendapat bahwapenelitian tindakan kelas merupakan suatu pencermatan terhadap kegiatan belajar berupa sebuah tindakan, yang sengaja dimunculkan dan terjadi dalam sebuah kelas secara bersama. Arikunto (2007:16) mengungkapkan bahwa pada penelitian tindakan kelas, ada empat langkah utama yang dilakukan, yaitu: 1) perencanaan; 2) pelaksanaan; 3) pengamatan; dan 4) refleksi.

Penelitian ini dilaksanakan di SMPN 2 Gunungsitoli Utara yang terletak di Kecamatan Gunungsitoli Utara Kota Gunungsitoli. Subjek penelitian ini adalah siswa kelas VII SMPN 2Gunungsitoli Utara yang terdaftar tahun pelajaran 2020/2021. Jumlah siswa sebanyak 28 orang. Waktu pelaksanaan penelitian ini, yaitupada semester ganjil Tahun Pembelajaran 2020/2021. Instrumen utama penelitian ini adalah peneliti sendiri. Peneliti juga berperan sebagai pelaksana pembelajaran di kelas dan dibantu oleh guru Bahasa Indonesia sebagai kolaborator dan juga sebagai perencana. Intrumen tambahan dalam penilitain ini adalah tes, untuk mengukur kemampuan siswa menyimpulkan isi teks laporan hasil observasi; lembar observasi digunakan untuk mengumpulkan data berupa aktivitas peneliti sebagai guru dan aktivitas siswa, kegiatan ini dilakukan oleh kolaborator; catatan lapangan digunakan untuk mencatat setting pembelajaran yang telah dilaksanakan; dan dokumentasi sebagai pendukung peneliti pada saat melaksanakan penelitian.

Ketuntasan individu dilihat dari hasil tes pada setiap akhir siklus yang diolah dengan menggunakan rumus sebagai berikut. 
Keterangan:

$$
\mathrm{NH}=\frac{S D S}{S M T} \times 100
$$

$\mathrm{NH}=$ Nilai hasil belajar

SDS $=$ Skor diperoleh siswa

SMT $=$ Skor maksimum tes, (Arikunto, 2008)

Kriteria keberhasilan siswa dapat ditetapkan dengan kategori penilaian sebagai berikut.

$$
\begin{array}{ll}
85 \%-100 \% & =\text { Baik sekali } \\
71 \%-84 \% & =\text { Baik } \\
65 \%-70 \% & =\text { Cukup } \\
<65 \% & =\text { Kurang }
\end{array}
$$

Ketuntasan klasikal dapat diukur secara individu.Seorang siswa dikatakan tuntas dalam belajarnya apabila sudah mencapai Kriteria Ketuntasan Minimal (KKM) yang ditentukan oleh sekolah, yaitu untuk mata pelajaran bahasa Indonesia 65.Ketuntasan belajar siswa diukur secara individu dengan menggunakan rumus sebagai berikut.

$$
\mathrm{PKK}=\frac{J S T}{J S S} \times 100 \%
$$

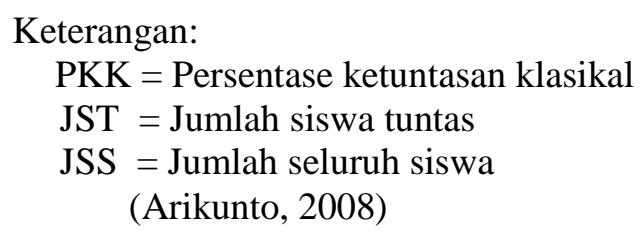

Indikator keberhasilan dalam penelitian ini adalah jika $\geq 75 \%$.

Aktivitas dalam analisis data, yaitu reduksi data, penyajian data, dan penarikan simpulan. Lebih jelas akan diuraikan sebagai berikut.

a. Reduksi Data

Reduksi data diartikan sebagai proses penyeleksian, menentukan fokus, menyederhanakan, meringkas dan mengubah bentuk data-data "mentah" yang ada dalam catatan lapangan. Pemusatan perhatian pada penyederhanaan, pengabstrakan dan transformasi data "kasar" yang muncul dari catatan-catatan tertulis di lapangan.Reduksi data merupakan suatu bentuk analisis yang menajamkan, menggolongkan, membuang yang tidak perlu, dan mengorganisasikan data dengan sedemikian rupa sehingga dapat disimpulkan. Dalam penelitian ini, peneliti bekerja sama dengan kolaborator untukmenganalisis dan memilah data kasar yang ditemui di lapangan untuk disimpulkan.

b. Penyajian Data

Penyajian data dapat dilakukan dengan cara memberikan uraian singkat, bagan, hubungan antara kategori dan sebagainya. Dalam proses penelitian kualitatif, penyajian data dalam penelitian ini dilakukan dengan menggunakan grafik dan tabel.

c. Penarikan Simpulan

Langkah selanjutnya adalah penarikan simpulan.Simpulan dapat bersifat sementara atau disebut juga kesimpulan awal.Simpulan dalam penelitian ini didukung oleh bukti-bukti yang valid dan konsisten sehingga dapat dikatan kredibel.

\section{HASIL DAN PEMBAHASAN}

Berdasarkan penelitian yang dilakukan, diperoleh hasil penelitian, yaitu pelaksanaan proses pembelajaran dengan menerapkan model Problem Centered Learning (PCL) pada materi menyimpulkan hasil observasi, pada siklus I, masih belum memuaskan yakni aktivitas belajar siswa selama mengikuti proses pembelajaran hanya mencapai nilai rata-rata 56,07\% predikat "kurang". Nilai sikap spritual (Penilaian KI-1) nilai rata-rata 69,25\%, masih belum mencapai 
predikat yang diharapkan yaitu masih pada predikat kurang. Nilai sikap sosial (Penilaian KI-2) nilai rata-rata $70,75 \%$. Perolehan nilai pengetahuan (Penilaian KI-3) nilai rata-rata yang diperoleh $=59,25 \%$ dengan predikat "kurang". (lampiran 23 tabel 20).

Berdasarkan temuan dari hasil refleksi siklus I, maka peneliti bersama dengan observer mempersiapkan beberapa hal, yaitu: penerapan langkah-langkah model Problem Centered Learning (PCL) lebih diperhatikan lagi oleh peneliti/guru; peneliti lebih memperhatikan lagi aktivitas siswa sehingga peningkatan hasil belajar siswa dapat meningkat pada siklus berikutnya dan tidak terdapat siswa yang ngantuk, malas, ribut.

Pada siklus II, didapatkan: 1) ada peningkatan pelaksanaan proses pembelajaran dengan menerapkan model Problem Centered Learning (PCL) pada materi menyimpulkan teks hasil observasi, mencapai rata-rata $88,23 \%$ (Sangat Baik); 2) aktivitas belajar siswa selama mengikuti proses pembelajaran melalui model Problem Centered Learning (PCL) pada materi menyimpulkan teks hasil observasi meningkat yakni mencapai rata-rata $73,27 \%$, predikat"Baik"; 3) nilai sikap spritual (Penilaian KI-1) meningkat nilai 82,67 dengan predikat "Baik"; 4). nilai sikap sosial (Penilaian KI-2) meningkat nilai 80,21dengan predikat "Baik"; 5) nilai pengetahuan (Penilaian KI-3) meningkat dengan rata-rata $=85,35$ dengan predikat "Sangat Baik". Terdapat 28 orang tuntas, dan 0 orang yang tidak tuntas.

Sebagaimana yang telah diuraikan sebelumnya bahwa hasil penelitian ini menunjukkan bahwa (1) ada peningkatan kemampuan menyimpulkan teks hasil observasi melalui model Problem Centered Learning (PCL) siswa Kelas VII SMP Negeri 2 Gunungsitoli Utara Tahun Pembelajaran 2018/2019. dan (2) aktivitas siswa dalam mengikuti proses pembelajaran melalui model Problem Centered Learning (PCL) meningkat karena melalui pembelajaran ini melibatkan siswa berpartisipasi aktif dalam mengikuti kegiatan belajar mengajar. Hal ini disebabkan karena Penulis menerapkan langkah-langkah pembelajaran semaksimal mungkin dengan penuh persiapan dalam proses pembelajaran. Dengan demikian secara praktis dari hasil penelitian dengan teori yang dikemukakan para ahli yakni :

Instarani (2012:37), mengungkapkan bahwa Problem-Centered Learning (PCL) yaitu rangkaian aktivitas pembelajaran yang menekankan kepada proses penyelesaian masalah yang dihadapi secara ilmiah. Model Problem-Centered Learning (PCL) barangkali menjadi metode yang paling dasar dalam memecahkan masalah karena dengan cara-cara tertentu kita selalu terlibatdalam proses penyelesaiannya. Pembelajaran yang melibatkan model Problem Centered Learning (PCL) akan melibatkan keterampilan proses, seperti kegiatan pengamatan atau observasi yang dibutuhkan untuk pengajuan hipotesis atau pengumpulan data.

Diharapkan akan menciptakan kondisi pembelajaran yang mendorong siswa untuk mencari tahu informasi dari berbagai sumber melalui observasi, dan bukan hanya diberi tahu. Secara konsep, Problem Centered Learning (PCL) lebih mengarah pada model pendidikan humanis, yaitu pendidikan yang memberikan ruang pada siswa untuk berkembang sesuai potensi kecerdasan yang dimiliki. Siswa menjadi pusat belajar, tidak menjadi obyek pembelajaran. Dengan demikian karakter, skill, serta kognisi siswa dapat berkembang secara lebih optimal.

\section{SIMPULAN}

Berdasarkan hasil penelitian ini, maka penulis menyimpulkan sesuai dengan temuan penelitian yang telah dilakukan adalah sebagai berikut:

1. Ada peningkatan kemampuan menyimpulkan teks hasil observasi melalui model Problem Centered Learning (PCL) siswa kelas siswa Kelas VII SMPN 2 Gunungsitoli Utara Tahun Pembelajaran 2020/2021. Hal tersebut sesuai dengan data hasil tes pengetahuan pada siklus I rata-rata nilai $=59,25 \%$ (predikat cukup). Nilai pengetahuan pada siklus II rata-rata $=85,35$ (predikat sangat Baik).

2. Aktivitas siswa dalam mengikuti proses pembelajaran melalui model Problem Centered Learning ( $P C L$ ) meningkat karena melalui pembelajaran ini melibatkan siswa berpartisipasi aktif dalam mengikuti kegiatan belajar mengajar. Hal tersebut sesuai data observasi aktivitas siswa pada siklus I = rata-rata 56,07\% (predikat kurang), dan siklus II $=$ rata-rata $73,27 \%$ (predikat Baik). 
3. Nilai sikap spiritual dalam proses pembelajaran pada siklus pertama nilai rata-rata $=69,25$ (predikat cukup) dan pada siklus kedua meningkat, dengan nilai rata-rata $=82,67$ (predikat baik). Nilai sikap sosial pada siklus pertama dengan nilai rata-rata $=70,75$ (predikat kurang) dan pada siklus kedua meningkat, dengan nilai rata-rata $=80,21$ (predikat cukup).

\section{DAFTAR PUSTAKA}

Arikunto, S dkk.(2007). Penelitian Tindakan Kelas. Jakarta: Bumi Aksara.

Dalman, 2014.Keterampilan Menulis . Jakarta: PT. Raja Grafindo Persada.

Herdiansyah. H. 2013. Wawancara, observasi dan focus Grup. Jakarta: Rajagrapindo persada.

Kemendikbud. 2016. Bahasa Indonesia. Jakarta: Pusat Kurikulum dan Perbukuan.

Tarigan, Henry Guntur. 2008. Membaca Sebagai Suatu Keterampilan Berbahasa. Bandung: Angkasa.

Rahim, Farida. 2009. Pengajaran Membaca di Sekolah Dasar. Jakarta: Bumi Aksara.

Tampubolon, DP. 2008. Kemampuan Membaca: Teknik Membaca Efektif dan Efisien. Bandung: Angkasa.

Instarani. 2012. 58 Model Pembelajaran Inovatif. Medan: Media Persada.

Munaf, Yarni. 2010. Rangkuman Pengajaran Keterampilan Membaca. Padang: FPBS UNP.

Klingner, Sharon Vaugh, dkk. 2007. Teaching Reading Comprehension to Student with Learning Difficulties. New York: The Guildford Dress.

Kurniawan. 2008. Pengaruh Model Pembelajaran Problem Centered Learning Terhadap Kemampuan Pemecahan Masalah Matematika Siswa SMP. Skripsi Universitas Pendidikan Indonesia. Bandung: Tidak diterbitkan.

Handayani, Y. 2011. Penerapan Model Pembelajaran Problem Centered Learning untuk Meningkatkan Kemampuan Pemecahan Masalah Matematika Siswa SMK. Skripsi UNPAN. Bandung: Tidak diterbitkan.

Yunaz, Febrisa. 2012. Pengaruh Penerapan Pendekatan Pembelajaran Problem Centered Learning terhadap Peningkatan Kemampuan Penalaran Adaptif Siswa SMP. Skripsi FPMIPA, Universitas Pendidikan Indonesia. Bandung: Tidak diterbitkan.

Yulianti, Nurlaela. 2013. Pengaruh Penalaran Pendidikan Problem Centered Learning terhadap Kemampuan Penalaran Induktif Siswa SMP. Skripsi FPMIPA Universitas Pendidikan Indonesia. Bandung: Tidak diterbitkan.

Kartono. 1980. Tersedia online. https://haviafotokopi.blogspot.co.id/2015/11/observasi-jenisjenis-dan-pengertian.html.

Djiwandono, M. Soenardi. 1990. Tes Bahasa dalam Pengajaran. Bandung: ITB Bandung. 